\title{
PENGARUH MEDIASI KEPUASAN KERJA PADA HUBUNGAN WORK- FAMILY CONFLICT DAN KOMITMEN ORGANISASIONAL
}

\author{
Veronika Agustini Srimulyani*) \\ Ardhika Vicki Prasetian**) \\ Fakultas Ekonomi Unika Widya Mandala Madiun
}

\begin{abstract}
The aim of this study is to examine whether work family conflict affects the organizational commitment mediated by job satisfaction in the lecturer profession. The populationin this studyis a lecturer instructural officerlevelcoursesat private higher institution in Madiun. The research subjects were 45 lecturerstructurallevelofficials. The data analyzed by using simple and multiple regression technique, using SPSS 17.0 for windows.

The result of path analysis indicate that:1) workfamily conflict have a direct effect on job satisfaction significantly; 2) workfamily conflict have a direct effect on organizational commitment significantly; 3) job satisfaction have a direct effect on organizational commitment significantly; 4) job satisfaction mediate the effect of workfamily conflict on organizational commitment significantly.
\end{abstract}

Keywords: WorkFamily Conflict, Job Satisfaction, OrganizationalCommitment

\section{A.Pendahuluan}

Keterlibatan diri secara penuh merupakan indikasi dari tingkat komitmen seseorang pada suatu organisasi. Komitmen organisasional anggota organisasi telah menjadi sebuah bahasan pada berbagai sektor seperti sektor publik, pemerintahan, sector nonprofit dan juga di internasional. Penelitian terhadap komitmen organisasional telah melibatkan banyak profesi seperti pendidikan, teologi, kesehatan, perhotelan, pekerja sosial dan kedokteran (Trimble, 2006).Dalam dunia kerja komitmen pegawai terhadap organisasi sangatlah penting sehingga beberapa organisasi berani unsur komitmen sebagai salah satu syarat untuk memegang jabatan/posisi yang ditawarkan dalam iklan lowongan pekerjaan. Dosen dengan tugas tambahan dengan menduduki jabatan seperti: ketua program studi, ketua jurusan, dekan sampai dengan jabtan tingkat rektorat di perguruan tinggi swasta (PTS) di Madiun khususnya, dituntut memiliki komitmen tinggi terhadap pekerjaannya baik dalam menjalankan tri dharma perguruan tinggi maupun tugas-tugas jabatan yang diembannya. Profesionalitas dan kualitas kerja para dosen tersebut merupakan indikasi dari adanya komitmen mereka terhadap instansi tempatnya bekerja, sehingga dengan memiliki komitmen tinggi terhadap instansi tempatnya bekerja dosen akan berusaha bekerja dengan sungguh-sungguh untuk mewujudkan tujuan yang ingin dicapai organisasi dengan sepenuh hati demi kemajuan instansi, sehinga PTS di Madiun dapat bersaing dengan PTS dan PTN di kota lain.

Komitmen organisasional dapat tumbuh manakala harapan kerja dapat terpenuhi oleh organisasi dengan baik, selanjutnya dengan terpenuhi harapan kerja akan menimbulkan kepuasan kerja (Setyawan, 2008). Seorang dosen yang memiliki kepuasan, baik kondisi internal maupun eksternal akan mendorong bekerja secara penuh untuk mencapai tujuan organisasi, melibatkan dirinya secara penuh terhadap organisasi.

Selain kepuasan kerja, faktor lain yang dapat menentukan karyawan memiliki komitmen organisasional atau 
tidak juga dapat dipengaruhi oleh konflik kerja-keluarga atau work family conflict.Sebuah konflik biasanya terjadi pada saat seseorang berusaha memenuhi tuntutan peran dalam pekerjaan dan usaha tersebut dipengaruhi oleh kemampuan orang yang bersangkutan untuk memenuhi tuntutan keluarganya, atau sebaliknya, di mana pemenuhan tuntutan peran dalam keluarga dipengaruhi oleh kemampuan orang tersebut dalam memenuhi tuntutan pekerjaannya (Frone dan Copper, 1992). Ketika seseorang mengalami konflik pekerjaan-keluarga, pemenuhan peran yang satu akan mengganggu pemenuhan peran yang lainnya sehingga akan berdampak terhadap kepuasan kerja dan komitmen organisasional.

Work family conflict ini termasuk dalam bentuk konflik inter role di mana tekanan peran dari pekerjaan dan keluarga saling bertentangan, sehingga partisipasi dalam satu peran membuatnya lebih sulit untuk berpartisipasi terhadap yang lainnya. Konflik peran terjadi ketika terdapat kebijakan atau tuntutan berbeda dan ini dapat menyebabkan ketidakpuasan individu bahkan berdampak pada penurunan komitmen dan kinerja organisasional. Work family conflict ini dapat menurunkan kepuasan kerja para dosen, sementara menurunnya kepuasan kerja dapat memberi dampak pada meningkatnya keinginan untuk keluar, meningkatnya absensi, dan menurunya komitmen organisasional. Jadi hal ini merupakan keadaan yang berbahaya bagi PTS tempat dosen bekerja, karena dapat menyebabkan pelaksanaan pekerjaan terganggu, yang akhirnya bisa menurunnya kinerja PTS yang bersangkutan.

Rantika dan Sunjoyo (2011) dalam penelitiannya menemukan bahwa kehidupan keluarga yang menganggu kehidupan pekerjaan dapat mempengaruhi komitmen organisasional pegawai.Kussuyarsana dan Soepatini (2008) dalam penelitiannya menemukan bahwa konflik kerja-keluarga berpengaruh negatif terhadap kepuasan kerja sedangkan penelitian yang dilakukan Kossek dan Ozeki (1998) menemukan bahwa konflik kerja-keluarga berpengaruh negatif pula terhadap komitmen organisasional.Luthans (2006) menyatakan bahwa terdapat hubungan yang kuat antara kepuasan kerja dan komitmen organisasional.

Berdasarkan konsep teori dan hasil penelitian terdahulu, maka secara konseptual ada beberapa faktor yang dapat mempengaruhi komitmen organisasionalparapegawai

yaituworkfamily conflict dan kepuasan kerja.

B. Landasan Teori dan

\section{Pengambangan Hipotesis}

Komitmen Organisasional

Menurut Robbins dan Judge

(2008) komitmen organisasional merupakan tingkat kekuatan seseorang dalam terlibat, mengidentifikasi, dan patuh terhadap organisasi. Menurut Allen dan Meyer dalam Rantika dan Sunjoyo (2011) mengemukakan komitmen organisasionalmemilikitigadimensiyaitu:

1) Komitmen afektifa dalah tingkat seberapa jauh seseorang karyawan secara emosi terikat, mengenal,dan terlibatdalamorganisasi.

2) Komitmen kontinuan merupakan suatu penilaian terhadap biaya (pengorbanan) yang terkait dengan meninggalkan organisasi.

3) Komitmen normatif merupakan perasaan bertanggung jawabuntuk 
tetap tinggal

(kesetiaan)dalamorganisasi.

Menurut Amstrong (1992) dalam Djuwita (2008) ada tiga penyebab komitmen organisasional yaitu 1) Rasa memiliki terhadap organisasi, 2) Rasa senang terhadap pekerjaan dan, 3) Sikap percaya kepada organisasi.

\section{Work-Family Conflict}

Filosofi sosial budaya dalam dunia pendidikan di Indonesia, menempatkan fungsi dan peran tenaga pendidik seperti guru dan dosen dalam berbagai macam peran, sehingga para pendidik di Indonesia tidak jarang diposisikan mempunyai peran ganda bahkan multi fungsi, terlebih bagi dosen yang menduduki jabatan struktural tingkat operasional (program studi). Para pendidik dituntut tidak hanya sebagai pendidik yang harus mampu mentransformasikan nilai-nilai ilmu pengetahuan, tetapi sekaligus sebagai penjaga moral bagi peserta didik. Adanya peran ganda pada profesi dosen dan tugas tambahan tersebut memunculkan konflik peran ganda dalam diri seorang dosen yang mempunyai konsekuensi atau dampak terhadap dosen, utamanya pada tingkat kepuasan kerja. Seorang individu seringkali memiliki peran ganda (multiple roles), karena selain sebagai dosen misalnya seseorang juga memiliki peran di keluarganya, di lingkungannya dan lain-lain. Peran-peran ini seringkali memunculkan konflik-konflik tuntutan dan konflik-konflik harapan.

Konflik adalah hubungan antara dua belah pihak atau lebih yang terjadi ketika individu memiliki rasa yang tidak dapat disejajarkan (Wirawan, 2010). Umumnya konflik sering dianggap menjadi hal yang harus dihindari, tetapi menurut Fisher et al.(2000) konflik itu tetap berguna dalam kehidupan dan merupakan bagian dari keberadaan kita. Di lain pihak menurut Jehn. K.A. et. al (2003) dalam Robbins dan Jugde, (2008) menyatakan konflik dapat menghambat kinerja kelompok yang disebut konflik disfungsional dan konflik-konflik yang memang dapat mendukung pencapaiaan tujuan kelompok dan semakin memperbaiki kinerja yangdisebut konflik fungsional.

Menurut Winardi (2007) konflik dalam organisasi dapat bersifat destruktif dan konstruktif. Konflik destruktif adalah konflik yang menimbulkan kerugian bagi individu atau individu lain dan atau organisasi yang terlibat di dalamnya. Konflik konstruktif dapat menimbulkan keuntungan bagi individu atau individuindividu lain dan atau organisasi yang terlibat di dalamnya. Ada pun keuntungan yang dapat dicapai dari konflik konstruktif adalah (1) kreativitas dan inovasi yang meningkat, (2) upaya yang meningkat, (3) kohesi dan komitmen yang makin kuat, (4) membantu menurunkan ketegangan. Konflik-konflik dengan intensitas moderat akan menimbulkan keuntungan bagi organisasi yang bersangkutan, sedangkan konflik sengan intensitas yang sangat rendah atau sangat tinggi dapat merugikan organisasi (Winardi, 2007).

Sementara itu, menurut Ching dalam Rantika dan Sunjoyo (2011) work family conflict secara umum dapat didefinisikan sebagai bentuk konflik peran dimana tuntutan peran dari pekerjaan dan keluarga secara mutual tidak dapat disejajarkan dalam beberapa hal. Menurut Greenhaus dan Beutell (1985) dalam Amelia (2010) workfamily conflict memiliki tiga bentuk yaitu:

a. Time-based conflict adalah banyaknya waktu yang dibutuhkan dalam memenuhi memenuhi kebutuhan salah 
satu peran (pekerjaan/ keluarga) sehingga menyebabkan seseorang mengalami kesulitan dalam memenuhi kebutuhan peran lainnya.

b. Strain-based conflict merupakan banyaknya tekanan yang timbul dalam melakukan salah satu peran (pekerjaan/keluarga) sehingga membuat seseorang mengalami kesulitan dalam memenuhi peran lainnya.

c. Behavior-based conflict yaitu adanya perilaku secara khusus yang dibutuhkan oleh salah satu peran (pekerjaan/keluarga) sehingga membuat seseorang mengalami kesulitan dalam memenuhi kebutuhan peran lainnya.

Salah satu dampak konflik seperti halnya work family conflict yang bersifat konstruktif adalah menyebabkan semakin kuatnya identitas kelompok, semakin kuatnya ikatan (kohesi) dan komitmen untuk mencapai tujuan bersama(Winardi, 2007). Hasil penelitian yang memperkuat hal tersebut dilakukan oleh Rantika dan Sunjoyo (2011) dan Lu et al. (2008) yang menemukan pengaruh positif signifikan family interfering with the work (FIW)terhadap komitmen organisasional pegawai. Dalam penelitian lain, yang dilakukan oleh Perrewe et al, dalam Namasivayam dan Zhao (2006); Purwaningsih dan Suprapti (2009); Rehman dan Waheed (2012) menunjukkan bahwa individu yang mengalami konflik antara pekerjaan dan keluarganya akan mengalami kekaburan dan menyebabkan terjadinya penurunan komitmen organisasional. Artinya work-familyconflict memiliki pengaruh negatif terhadap komitmen organisasional, hal ini berarti semakin tinggi workfamily conflict, maka semakin rendah komitmen organisasional.Berdasarkan kajian teori dan beberapa penelitian terdahulu maka hipotesis dirumuskan sebagai berikut.

$\begin{array}{cc}\text { Hipotesis } \quad 1: & \text { Work-family } \\ \text { conflictberpengaruh } & \text { signifikan } \\ \text { terhadap komitmen organisasional } \\ \text { Kepuasan Kerja }\end{array}$

Kepuasan kerja didefinisikan sebagai sikap umum individu terhadap pekerjaannya (Robbins, 2003). Kepuasan kerja merupakan dambaan setiap individu yang sudah bekerja. Masing-masing karyawan memiliki tingkat kepuasan yang berbeda sesuai dengan nilai yang dianutnya. Semakin banyak aspek-aspek dalam pekerjaan yang sesuai dengan keinginan dan kebutuhan karyawan tersebut maka semakin tinggi pula kepuasan yang dirasakan, demikian pula sebaliknya. Robbins dan Judge (2008) mengemukakan bahwa kepuasan kerja dipengaruhi oleh tantangan pekerjaan, gaji, kondisi kerja, kecocokan kepribadian dan pekerjaan serta rekan kerja.

Dalam Teori Herzberg, terdapat dua faktor yang menyebabkan kepuasan dan ketidakpuasan. Pertama, faktor motivator merupakan karakteristik pekerjaan berkaitan dengan kepuasan pekerjaan, yaitu sejumlah kebutuhan yang apabila dipenuhi akan menimbulkan kepuasan tetapi jika tidak dipenuhi akan mengurangi kepuasan. Kedua, faktor hygiene merupakan karakteristik pekerjaan berkaitan dengan ketidakpuasan pekerjaan, yaitu sejumlah kebutuhan yang apabila dipenuhi tidak akan meningkatkan motivasi, tetapi jika tidak dipenuhi akan menimbulkan kepuasan. Baik faktor motivator dan hygiene sangat penting bagi pemeliharaan tingkat kepuasan pegawai. Kedua faktor ini selalu berjalan seiring dengan aktivitas kerja seseorang dalam organisasinya. Faktor yang termasuk dalam faktor motivator adalah prestasi kerja, promosi, 
tanggung jawab, pengakuan, dan kerja itu sendiri. Faktor yang termasuk hygiene faktor adalah hubungan antar pribadi, keamanan kerja, kehidupan pribadi, keamanan kerja, kebijakan administrasi, gaji, status, supervisi, dan kondisi kerja.

Menurut Davis (1996) bahwa kepuasan kerja merupakan seperangkat perasaan karyawan yang menyenangkan atau tidak menyenangkan. Jika seorang dosen yang mengalami konflik pekerjaankeluarga dalam Teori Herberg termasuk dalam faktor hygiene, tentu akan merasa tidak nyaman terhadap pekerjaannya, dan dapat mengakibatkan rendahnya kepuasaan kerja. Penelitian yang dilakukan oleh Agustina (2008); Rathi dan Barath (2012) menunjukkan hasil bahwa semakin tinggi work family conflict yang dialami, maka semakin rendah kepuasan kerja yang dirasakan. Atau semakin rendah tekanan pekerjaan dan keluarga yang dirasakanseseorang maka akan semakin tinggi tingkat kepuasan yang dirasakan, atau sebaliknya.

\section{Hipotesis 2: Work-family \\ conflictberpengaruh signifikan terhadap kepuasan kerja. \\ Menurut Griffin dan Ebert (1996)} ada pengaruh kepuasan kerja terhadap komitmen dan produktivitas, bahwa bila dibandingkan dengan para pekerja yang tidak puas, karyawan yang puas lebih berkomitmen dan setia. Penelitian Restuningdiah (2009) menemukan hubungan yang kuat antara kepuasan kerja dan komitmen organisasional. Hasil penelitian oleh Purwaningsih dan Suprapti (2009)menunjukkan bahwa ada pengaruh positif signifikan kepuasan kerja terhadap komitmen organisasional. Penelitian yang dilakukan oleh Chiun-Lo dan Ramayah (2011), dari penelitian ini didapatkan temuan bahwa dengan dilakukan mentoring yang baik pada pekerjaan itu sendiri, promosi, supervisi pimpinan, dan kelompok kerja akan menimbulkan kepuasan kerja dan kepercayaan diri kepada pegawai. Dosen yang puas akan lebih komit pada organisasi, punya sikap yang lebih menyenangkan terhadap pekerjaan dan organisasi, menjadi lebih sabar lebih mungkin membantu rekan kerjanya, mempunyai keinginan yang lebih besar untuk tidak meninggalkan pekerjaannya dibandingkan dosen yang tidak puas. Sebuah penjelasan logis dari hasil ini dapat bahwa komitmen organisasional merupakan fungsi dari kepuasan kerja. Berbagai dimensi kepuasan kerja seperti kepuasan dengan gaji, rekan kerja, supervisi, dan bekerja sendiri dibutuhkan oleh para pekerja untuk memenuhi kebutuhan dasar mereka. Ketika kebutuhan dosen terpenuhi,ada kemungkinan bahwa tingkat komitmen organisasional dimanifestasikan oleh dosen akan menjadi tinggi.

Hipotesis 3: Kepuasan kerja berpengaruh signifikan terhadap komitmen organisasional.

Penelitian ini sejalan dengan penelitian Melly (2004) yang menyatakan bahwa hubungan antara konflik peran dan kepuasan kerja tidak terbukti negatif. Yousef (2002) mengemukakan bahwa seseorang yang mengalami konflik peran dan ambiguitas peran pada tingkat yang tinggi sebagai sumber dari stres akan kurang puas dengan pekerjaannya. Di sisi lain, tingkat kepuasan kerja yang dirasakan seseorang dapat sebagai pemediasi hubunganwork-family conflict terhadap komitmen organisasional seseorang pada organisasi tempat bekerja. Hal ini dibuktikan pada penelitianyang dilakukan oleh Rantika dan Sunjoyo (2011) menguji pengaruhwork family conflict terhadap komitmen organisasional 
dengan kepuasan kerja sebagai mediasi, menunjukkanhasil bahwa work family conflict yang terdiri dari work interfering with the family dan family interfering with the work berpengaruh signifikan terhadap kepuasan kerja, dan kepuasan kerja berpengaruh signifikan terhadap komitmen organisasional.

Hipotesis 4:kepuasan kerja memediasi pengaruhwork family conflik terhadap komitmen organisasional.

Kerangka penelitian diadaptasi dari beberapa penelitian terdahulu digambarkan sebagai berikut.

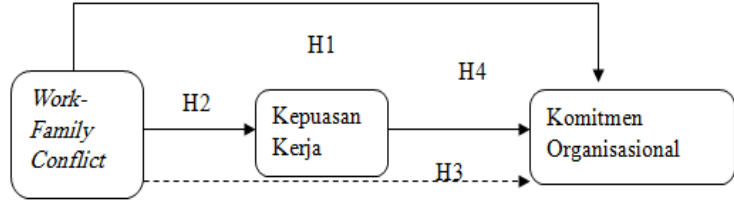

Gambar 1. Model KerangkaPikir Penelitian

3. Metode Penelitian

Populasi, Sampel dan Teknik Pengambilan Sampel

Menurut Sugiyono (2003) populasi adalah wilayah generalisasi yang terdiri atas: obyek/subyek yang mempunyai kualitas dan karakteristik tertentu yang ditetapkan oleh peneliti untuk dipelajari dan kemudian ditarik kesimpulannya. Populasi yang diambil berasal dari dosen pejabat struktural tingkat Jurusan/Program Studi yang menjabat di 12 Perguruan Tinggi Swasta kota Madiun, sebagai berikut:

Tabel 1.Nama dan Alamat Perguruan Tinggi Swasta Kota Madiun

\begin{tabular}{ll}
\hline \multicolumn{1}{c}{ Nama Perguruan Tinggi Swasta } & \multicolumn{1}{c}{ Alamat } \\
\hline Unika Widya Mandala Madiun & Jl. Manggis No. 15-17 Madiun \\
Universitas Islam Indonesia & Jl. Ponorogo No.70 Madiun. \\
Universitas Merdeka Madiun & Jl. Serayu Tromol Pos 12 Madiun. \\
IKIP PGRI Madiun & Jl. Setia Budi No. 85 Madiun. \\
STISIP Muhammadiyah Madiun & Jl. Mayjen Panjaitan No. 18 Madiun. \\
STKIP Widya Yuwana Madiun & Jl. Soegijopranoto Tromol Pos 13 Madiun \\
STIE Dharma Iswara & Jl. Auri 14-16 Madiun. \\
STT Dharma Iswara & Jl. Auri 14-16 Madiun. \\
STIKES Bhakti Husada Mulya & Jl. Taman Praja No. 25 Madiun. \\
Akbid Muhammadiyah Madiun & Jl. Mayjen Panjaitan No. 18 Madiun. \\
Akbid Global Medika & Jl. Margobawero Gg III Mojorejo, Madiun. \\
ASM Widya Mandala Madiun & Jl. Manggis No. 15-17 Madiun \\
\hline
\end{tabular}
Sumber: Data primer, 2014.

Alasan yang mendasari pengambilan populasi adalah dosen yang memiliki jabatan struktural tingkat program studi adalah karena jabatan Ketua dan Sekretaris program studi adalah jabatan dalam tingkatan operasional yang sering berurusan langsung dengan masalah operasional pelaksanaan Tri Dharma Perguruan Tinggi setiap harinya. semua anggota populasi digunakan sampel (Sugiyono, 2013). Dari 12 Perguruan Tinggi Swasta (PTS) yang ada di Kota Madiun, hanya 9 PTS yang disurvei, karena 3 dari 12 PTS di Madiun tersebut tidak bersedia untuk diteliti, dengan jumlah populasi sebanyak 55 dosen yang memiliki jabatan strukural tingkat program studi.Jumlah sampel ditetapkan sejumlah populasi, sesuai pendapat Arikunto (2006) yang 
menyatakan bahwa: dalam pengambilan sampelapabila subyeknya kurang dari 100, lebih baik diambil semua sehingga penelitiannya merupakan penelitian populasi. Kuesioner yang dibagikan ke dosen 9 PTS kota Madiun sebanyak 55 kuesioner dan terdapat 45 kuesioner yang kembali dan diisi lengkap (response rate sebanyak $81,81 \%$ dari kuesioner yang dibagikan).

\section{Instrumen}

Keseluruhan item pernyatan yang digunakan sebagai instrumen penelitian berjumlah 31 item pernyataan, yang terdiri dari 12 item pernyataan untuk mengukur work-family conflict, 10 item pernyataan untuk mengukur kepuasan kerja dan sekaligus berperan sebagai variabel kontrol; dan 9 item pernyatan untuk mengukur komitmen organisasional.

Instrumen pengukuran work-family conflictdiadopsi dari 6 indikator work family conflict dari Greenhaus dan Beutell dalam Amelia (2010) meliputi: time based conflict work interfering with the family, strain based conflict work interfering with the family, behavior based conflict work interfering with the family, time based conflict family interfering with the work, strain based conflict family interfering with the work, behavior based conflict family interfering with the work. Instrumen pengukuran kepuasan kerja diadopsi dari 5 indikator kepuasan kerja dari Robbins dan Judge (2008) yang meliputi: kepuasan atas tantagan pekerjaan, gaji atau imbalan, kondisi kerja, kecocogan pribadi dan pekerjaan, rekan kerja. Instrumen pengkuran komitmen organisasional diadopsidari 3 indikator komitmen organisasional dari Amstrong (1992) yang meliputi: rasa memiliki lembaga, rasa senang terhadap pekerjaan, dan sikap percaya pada lembaga.

\section{Hasil dan Pembahasan}

Profil responden penelitian ini disajikan pada tabel 2 meliputi umur, jenis kelamin, pendidikan, lama bekerja, status pekerjaan, dan jabatan di institusi.

Tabel 2. Profil Responden

\begin{tabular}{lll}
\hline \multicolumn{1}{c}{ Keterangan } & Jumlah (Orang) & Presentase (\%) \\
\hline Umur & 1 & $2,22 \%$ \\
$<26$ tahun & 21 & $46,67 \%$ \\
$26-35$ tahun & 15 & $33,33 \%$ \\
36-45 tahun & 8 & $17,78 \%$ \\
$>46$ tahun & & \\
Jenis Kelamin & 30 & $66,67 \%$ \\
Perempuan & 15 & $33,33 \%$ \\
Laki-laki & & \\
Pendidikan & 10 & $22,22 \%$ \\
S-1 & 35 & $77,78 \%$ \\
S-2 & 0 & $0 \%$ \\
S-3 & & \\
Masa Bekerja & 20 & $44,44 \%$ \\
$<5$ tahun & 11 & $24,44 \%$ \\
5-10 tahun & 4 & $4,89 \%$ \\
11-15 tahun & 10 & $22,22 \%$ \\
$>15$ tahun & & \\
Status Pekerjaan & 45 & $100 \%$ \\
Dosen tetap & &
\end{tabular}




\begin{tabular}{lcl}
\hline \multicolumn{1}{c}{ Keterangan } & Jumlah (Orang) & Presentase (\%) \\
\hline $\begin{array}{l}\text { Dosen tidak tetap } \\
\quad \text { Jabatan }\end{array}$ & 0 & $0 \%$ \\
$\begin{array}{l}\text { Ketua Jurusan/Program Studi } \\
\text { Sekertaris Jurusan/Program Studi }\end{array}$ & 27 & $60 \%$ \\
\hline
\end{tabular}

Sumber: Data primer, 2014.

\section{Uji Validitas dan Reliabilitas}

Dari hasil uji validitas yang diolah dengan membandingkan $\mathrm{r}$ hitung $>$ dari $\mathrm{r}$ tabel $(0,298)$, bila nilai $r$ hitung $>r$ tabel maka dapat dinyatakan valid. Untuk variabel workfamily conflict ada 2 item yang tidak memiliki nilai $\mathrm{r}$ hitung $>\mathrm{r}$ tabel. Untuk variabel kepuasan kerja ada 1 item yang tidak memiliki nilai $\mathrm{r}$ hitung $>$ r tabel, sedangkan untuk variabel komitmen organisasional semua item pernyataan memiliki nilai $\mathrm{r}$ hitung $>\mathrm{r}$ tabel. Dari hasil uji reliabilitas diperoleh nilai Cronbach's Alpha dari tiga variabel yang diteliti lebih besar (>) 0,60 (Nunnally, 1967 dalam Ghozali, 2006), sehingga dapat disimpulkan ke tiga variabel dalam penelitian ini reliabel.

\section{Tabel 3. Hasil Uji Reliabilitas}

\begin{tabular}{|c|c|c|c|}
\hline Variabel & $\begin{array}{l}\text { Alpha } \\
\text { Hitung }\end{array}$ & $\begin{array}{l}\text { Cronbach } \\
\text { Alpha }\end{array}$ & Keterangan \\
\hline Work-Family Conflict (WFC) & 0,897 & 0,600 & Reliabel \\
\hline Kepuasan kerja & 0,869 & 0,600 & Reliabel \\
\hline Komitmen Organisasional & 0,814 & 0,600 & Reliabel \\
\hline
\end{tabular}

Sumber: Output SPSS-Uji reliabilitas

Tabel 4. Ringkasan Uji Causal Step dengan Analisis Regresi Sederhana dan Berganda

\begin{tabular}{|c|c|c|}
\hline Varia & $\begin{array}{l}\text { B (Standar-dized } \\
\text { Coefficients) }\end{array}$ & Sig \\
\hline
\end{tabular}

Pengaruh Langsung

WFC $\rightarrow$ Komitmen Organisasional

WFC $\rightarrow$ Kepuasan Kerja

0,424

0,323

$0,004 \quad 0,180 \quad 0,161$

Signifikan

Kepuasan kerja $\rightarrow$ Komitmen Org

0,506

$0,031 \quad 0,104$

0,083

Signifikan

Pengaruh Tidak Langsung: Kepuasan Kerja sebagai variabel kontrol

\begin{tabular}{llllll} 
WFC $\rightarrow$ Komitmen Organisasional & 0,291 & 0,034 & 0,332 & 0,300 & Signifikan \\
Kepuasan Kerja $\rightarrow$ Komitmen Org & 0,412 & 0,004 & 0,332 & 0,300 & Signifikan \\
\hline
\end{tabular}

Sumber: Output SPSS-Analisis regresi linier dan uji koefisien determinasi

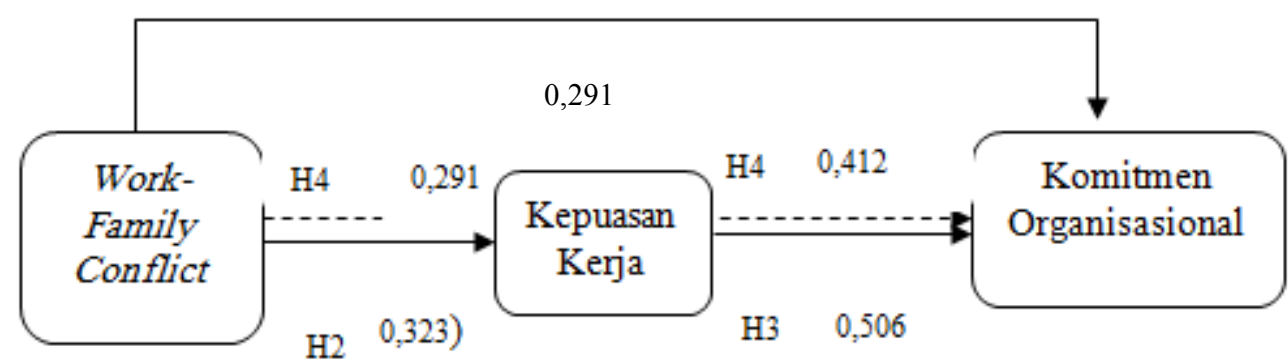

Gambar 2. Model yang Terbentuk 
Pada tabel 4, dilihat bahwa workfamily conflict berpangaruh signifikan terhadap komitmen organisasional, dengan arah positif, hal ini dapat dilihat dari $P$ value $($ sig $)<0,05$. Hasil penelitian ini mendukung penelitian Rantika dan Sunjoyo (2011); Lu et al. (2008) menunjukkan bahwa work family conflict berpengaruh positif signifikan terhadap komitmen organisasional. Hasil penelitian ini mengindikasikan bahwa work family conflict yang dialami para dosen yang menjabat di tingkat program studi merupakan konflik fungsional karena masih dalam intensitas rendah sehingga mengembangkan komitmen organisasional para dosen secara keseluruhan yang meliputi komitmen organisasional para dosen. Hal ini memperkuat pendapat Winardi (2007) bahwa konflik yang bersifat konstruktif dapat menguntungkan bagi organisasi yang bersangkutan dan salah satu keuntungannya adalah ikatan (kohesi) dan komitmen yang makin kuat; konflik yang terjadi dapat menyebabkan semakin kuatnya identitas kelompok, semakin kuatnya ikatan (kohesi) dan komitmen untuk mencapai tujuan bersama.

Pada tabel 4, dilihat bahwa workfamily conflict berpangaruh signifikan terhadap kepuasan kerja, dengan arah positif, hal ini dapat dilihat dari $\mathrm{P}$ value (sig) < 0,05. Hasil penelitian ini mendukung hasil penelitian Rantika dan Sunjoyo (2011); Anafarta (2011) menunjukkan hasil bahwa work family conflictberpengaruh positif signifikanterhadap kepuasan kerja. Hasil penelitian ini mengindikasikan bahwa work family conflict yang dialami para dosen yang menjabat tingkat program studi, membuat para dosen merasakan tantangan atas work family conflict(konflik peran ganda yang dialami), sehingga membuat para dosen merasakan pekerjaan yang sedang mereka jalankan menimbulkan kepuasan tersendiri.Ketika seseorang berhasil mengelola work family conflict yang dirasakan menjadi konflik fungsional, dalam hal ini menciptakan kepuasan kerja para dosen. Temuan ini mengindikasikan bahwa salah satu keuntungan dari konflik konstruktif adalah kreativitas dan inovasi yang meningkat; hal ini terjadi ketika seseorang mengalami konflik, seseorang akan berupaya agar mereka melaksanakan pekerjaannya atau berperilaku dengan cara-cara baru yang lebih baik, dan saat seseorang berhasil, tercapailah kepuasan dalam bekerja atau dalam peran kerjanya.

Pada tabel 4, dilihat bahwa kepuasan kerja berpangaruh signifikan terhadap komitmen organisasional, dengan arah positif, hal ini dapat dilihat dari $P$ value $($ sig) $<0,05$. Hasil penelitian ini sesuai mendukung penelitian Restuningdiah (2009); Purwaningsih dan Suprapti (2009); dan Chiun-Lo dan Ramayah (2011). Hasil penelitian ini juga mendukung teori, seperti yang diungkapkan oleh Griffin dan Ebert (1996), adanya pengaruh kepuasan kerja terhadap komitmen dan produktivitas, bahwa bila dibandingkan dengan para pekerja yang tidak puas, pekerja yang puas lebih berkomitmen dan setia. Anggota organisasi yang terpuaskan dengan tugas-tugas dan lingkungan kerjanya, yang mengidentifikasikan dirinya dengan organisasi, dan yang terlibat dengan aktivitas-aktivitas organisasi, sesungguhnya cenderung komit dan bisa dikontrol. Hal ini menujukkan semakin puas dosen bekerja dalam suatu lembaga maka semakin tinggi juga tingkat komitmen organisasional dalam diri dosen tersebut. Hasil penelitian ini mengindikasikan bahwa tingkat kepuasan kerja yang dirasakan para dosen atas aspek tantangan pekerjaan, gaji atau imbalan yang sesuai, kondisi kerja yang baik, kecocokan pribadi dan pekerjaan serta dukungan rekan kerja dapat meningkatkan komitmen organisasional para dosen (rasa memiliki terhadap lembaga, rasa senang terhadap lembaga, dan sikap percaya pada lembaga).

Untuk menganalisis pengaruh kepuasan kerja sebagai variabel mediasi 
antara pengaruh variabel bebas (workfamily conflict) terhadap variabel terikat (komitmen organisasional) dengan cara membandingkan nilai standardized (beta) sebelum dan sesudah dikontrol oleh kepuasan kerja (tabel 4). Mengacu pendapat Baron dan Kenny (1986) dalam Srimulyani (2010) menyatakan bahwa suatu variabel berfungsi sebagai variabel mediasi (perantara) jika: 1) Variabel independen secara signifikan mempengaruhi variabel perantara; 2) Variabel perantara secara signifikan mempengaruhi variabel independen; 3) Variabel independen secara signifikan mempengaruhi variabel dependen; 4) Pengaruh variabel independen terhadap variabel dependen menurun secara dikontrol variabel perantara. Lebih lanjut, Baron dan Kenny (1986) dalam Srimulyani (2010) menyatakan bahwa peran variabel perantara dapat dikelompokkan menjadi dua yaitu i) partial mediation effect, terjadi jika persamaan regresi setelah dimasukkan variabel perantara sebagai variabel kontrol, koefisien hubungan/pengaruh variabel independen terhadap variabel dependen akan menurun tetapi masih signifikan; ii) Full mediation effect, terjadi jika persamaan regresi setelah dimasukkan variabel perantara sebagai variabel kontrol, koefisien hubungan/pengaruh variabel independen terhadap variabel dependen menurun, dan tidak signifikan.

Hasil tabel 4dapat diketahui bahwa variabel kepuasan kerja memenuhi syarat sebagai variabel mediating atas pengaruh variabel bebeas terhadap variabel terikat. Tabel 4, dapat dilihat bahwa pengaruh work family conflict terhadap komitmen organisasional menurun setelah dikontrolkepuasan kerja yaitu yang semulanya 0,424 turun menjadi 0,291 tetapi masih signifikan. Hal iniberarti kepuasan kerja berperan sebagai pemediasi parsial (partial mediation effect) atas pengaruh work-family confict terhadap komitmen organisasional adalah sebagai perantara parsial, hal ini dilihat dari koefisien beta menurun setelah dikontrol variabel kepuasan kerja, tetapi masih signifikan. Hasil penelitian ini mengindikasikan bahwa besarnya pengaruh workfamily conflict dari seorang dosen pejabat struktural tingkat program studi, dapat secara langsung mengembangkan komitmen organisasional, namun di sisi lain workfamily conflict juga menjadi sumber dalam mengembangkan kepuasan kerja, yang selanjutnya berpangaruh pada pengembangan komitmen organisasional dosen.

\section{Kontribusi Manajerial dan Kontribusi Teoretikal \\ Work-family conflict yang dialami} dosen yang menjabat pada level program studi bersifat fungsioal, hal ini meningkatkan kepuasan kerja dan komitmen organisasional. Hal ini perlu menjadi perhatian pimpinan level dekanat ke atas pada PTS se-Kota Madiun, agar tetap menjaga agar konflik yang dirasakan dosen yang menjabat level operasional ini tetap bersifat fungsional. Mengacu pada teori Herzberg, dua faktor yang menyebabkan kepuasan dan ketidakpuasan para dosen perlu menjadi perhatian pimpinan, yang meliputi: prestasi kerja, promosi, tanggung jawab, pengakuan, dan kerja itu sendiri, hubungan antar pribadi, keamanan kerja, kehidupan pribadi, keamanan kerja, kebijakan administrasi, gaji, status, supervisi, dan kondisi kerja. Jika faktorfaktor tersebut terpenuhi, sebagai staf profesional yang mengelola operasional jasa pendidikan sebagai jasa utama dari sebuah lembaga pendidikan, tentunya akan berupaya terlibat secara penuh demi kemajuan program studi yang dipimpinnya, yang pada akhirnya akan berdampak pada kinerja perguruan tinggi, mengingat persaingan perguruan tinggi demikian ketatnya dan semakin tingginya tuntutan pengguna alumni atas kualitas lulusan suatu lembaga pendidikan tinggi.

Dari hasil penelitian ini, dapat memberikan tambahan wawasan dan memperkuat beberapa ahli yang memiliki pandangan bahwa konflik itu dapat 
berdampak positif pada organisasi apabila manajemen konflik dapat dilakukan secara efektif, sehingga dapat mengembangkan perilaku-perilaku positif organisasional seperti: meningkatkan kepuasan atas pekerjaan, dan meningkatkan rasa komit terhadap pekerjaan maupun organisasi tempat kerja.

\section{Kesimpulan, Keterbatasan, dan Saran}

Kesimpulan dari hasil penelitian yang telah dilakukan adalah: 1) workfamily conflict berpengaruh signifikan terhadap kepuasan kerja; 2)Work family conflict berpengaruh signifikan terhadap komitmen organisasional; 3) kepuasan kerja berpengaruh signifikan terhadap komitmen organisasional; 4) Work-family conflict berpengaruh tidak langsung terhadap komitmen organisasional dengan kepuasan kerja sebagai pemediasi.

Ada pun keterbatasan dalam penelitian ini adalah 1) sampel penelitian yang diambil tidak dalam jumlah yang banyak (hanya 45 , idealnya minimal 5 kali dari item pernyataan), hal ini mengindikasikan sampel tidak bersifat random; 2) daerah cakupan dalam penelitian ini tergolong sempit, hanya mencakup Perguruan Tinggi Swasta seKota Madiun. Berdasar hasil penelitian yang telah dilakukan, maka peneliti memberikan beberapa saran untuk penelitian selanjutnya sebagai berikut: 1) diharapkan penelitian selanjutnya memisahkan sumber penyebabwork family conflict menjadi work interfering with the family dan family interfering with the work, sehingga untuk penelitian selanjutnya mampu menjelaskan sumber penyebab yang utama konflik pekerjaan dan keluarga ; 2) pengumpulan data dapat pula ditambah dengan wawancara kepada subyek penelitian agar data primer yang disebarkan benar-benar menjelaskan keadaan yang sebenarnya; 3) penelitian selanjutnya diharapkan memperluas populasi memperbanyak sampel yang digunakan agar dalam penentuan hubungan antar variabel benar-benar menjelaskan hubungan yang sesuai dengan keadaan yang sebenarnya.

\section{DAFTAR PUSTAKA}

Amelia, Anisah. (2010). Pengaruh Workto-Family Conflict dan Family-to-Work Conflict Terhadap Kepuasan dalam Bekerja, Keinginan Pindah Tempat Kerja, dan Kinerja Karyawan. Jurnal Ekonomi dan Bisnis, 4 (3),161-247.

Anafarta, Nilgun. (2011). The Relationship Between Work-Family Conflitc and Job Satisfaction: A Structural Equation Modeling (SEM) Approach. International Journal of Business and Management, 6 (4), 168-177.

Chiun Lo, May dan Ramayah, T. (2011). Mentoring and job satisfaction in Malaysian SMEs, Journal of Management Development, 30 (4), 427 -440.

Djuwita, Tita Meirina. (2008). Komitmen Organisasi.

tdjwita.blogspot.com/2008/05/komit men-organisasi-oleh-titameirina.htm? $m=1$, diakses 3 Desember 2013.

Fisher, Simon, Jawed Ludin, Stave Williams, Dekha Ibrahim Abdi, Richard Smith, dan Sue Williams (penyunting). (2000). Mengelola Konflik: Ketrampilan dan Strategi untuk Bertindak. Jakarta: Zed Books Ltd.

Frone, M.R., Russell, M. and Cooper, M.L. (1992). Antecedents and outcomes of work-family conflict: testing a model of the work-family interface. Journal of Applied Psychology, Vol. 77, No. 1, pp. 65-78

Ghozali, Imam. (2002). Aplikasi Analisis Multivariate dengan Program SPSS. Semarang: Badan Penerbit Universitas Diponegoro.

(2006). Aplikasi Analisis Multivariate dengan Program SPSS. Semarang: Badan Penerbit Universitas Diponegoro.

Griffin, Ricky W, and R.J Ebert. (1996). Business. Edisi Ke-4.Jilid 1.Terjemahan oleh Wgiono Ismangil. Jakarta: Prenhallindo. Edisi Bahasa Indonesia. 
Lu, Luo, Shu-Fang Kao, Ting-Ting Kao, Hsin-Pei $\mathrm{Wu}$, dan Cary L. Cooper. (2008). WorkFamily Demends, Work Flaxibility, Work/Family Conflict, and Their Consequences at Work: A national Probability Sample in Taiwan. International Journal of Stress Managemant, 15 (1), 1-21.

Luthans, Fred. (2006). Perilaku Organisasi.Edisi 10. Yogyakarta: Andi.

Purwaningsih, Sri U dan Suprapti, A Riani. (2009). Pengaruh Konflik Keluarga-Pekerjaan Terhadap Komitmen Organisasidengan Kepuasan Kerja Sebagai Variabel Mediasi. Fokus Manajerial, 7 (1), 19-28.

Rantika, Renny dan Sunjoyo. (2011). Pengaruh Konflik Kerja-Keluarga Terhadap Komitmen Oragnisasi yang Dimediasi oleh Kepuasan Kerja Pada Profesi Perawat di Rumah Sakit Umum Daerah (RSUD) DR. Moewardi Surakarta. Jurnal Manajeman Teori dan Terapan, 2 (4), 28-43.

Rathi, Neerpal dan Barath M. (2012). Work-Family Conflict and Job and Family Saticfaction: Moderating Effect of Social Support amoung Police Personel. Working Paper, 123.

Restuningdiah, Nurika. (2009). Pengaruh Komitmen Profesional terhadap Kepuasan Kerja Akuntan Pendidik melalui Komitmen Organisasi. Jurnal Ekonomi Bisnis, 3 (14).

Robbins, Stephen P dan Judge Timothy A. (2008). Perilaku Organisasi edisi 12. Jakarta. Salemba Empat.

Robbins, S.P. (2003). Organizational Behavior, Edisi kedelapan. New Jersey: Prentice Hall International.
Srimulyani, V. A. (2010). Antesenden Affective Commitment Dosen Tetap pada Perguruan Tinggi Swasta di Madiun, Ngawi, dan Ponorogo. Widya Warta, 01.

Soediro, Achmad. (2008). Pengaruh Timbal Balik Antara Kepuasan Kelauarga Dan Kepuasan Kerja dan Komitmen Kerja Serta Dampaknya Terdadap Prestasi Kerja dan Karier Dosen". Jurnal Manajemen dan Kewirausahaan,10 (1), 38-49.

Winardi. (200). Manajemen Konflik (Konflik Perubahan dan Penegembangan). Bandung: CV. Madar Maju.

Wirawan. (2010). Konflik dan Manajeman Konflik (Teori, Aplikasi, dan Penelitian). Jakarta: Salemba Humanika.

Trimble, Douglas E. 2006. “Organizational Commitment, Job Satisfaction, and Turnover Intention of Missionaries." Journal of Psychology and Theology, Vol. 34, No. 4, h. 349-360.

*)Penulis Utama: Veronika Agustini Srimulyani, SE., M.Si. Alumni UNS (S1), dan UNAIR (S2); dosen tetap di Fakultas Ekonomi Unika Widya Mandala Madiun, sejak tahun 1997 hingga sekarang; pengampu mata kuliah Kewirausahaan, Kepemimpinan, dan Perilaku Organisasi; terlibat aktif dalam pengembangan UMK batik tulis di Kota Madiun.

**)Anggota Penulis: Ardhika Vicki Prasetian, SE; Alumni Unika Widya Mandala Madiun, Staff Ahli PT Bumi Pembangunan Pertiwi Madiun. 
A. Identitas Responden

Nama

KUESIONER

Umur

Jenis Kelamin Pendidikan

Masa bekerja :

Status Pekerjaa Dosen PTS Jabatan

\section{B. Pertanyaan Penelitian}

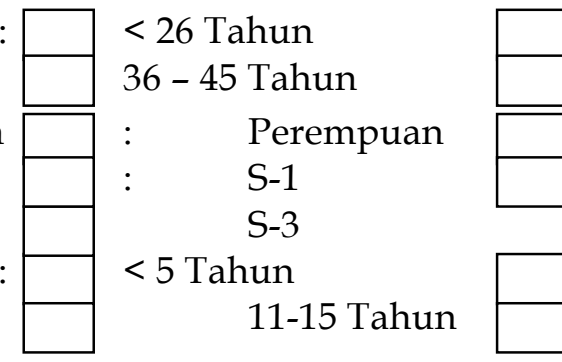

Dosen Tetap (boleh tidak diisi)

26-35 Tahun

$>46$ tahun

Laki-laki

S-2

\section{5-10 Tahun}

$>15$ Tahun

Dosen Tidak Tetap

Pilihlah salah satu jawaban yang paling sesuai menurut pendapat Anda dengan memberikan tanda checklist $(\sqrt{ })$ pada jawaban yang Anda anggap sesuai.

Keterangan jawaban:

Pernyataan No. 1-12

SS : Sangat setuju

$\mathrm{S} \quad$ : Setuju

$\mathrm{N} \quad$ : Netral

TS : Tidak setuju

STS : Sangat tidak setuju
Pertanyaan No. 13-31

SS : Sangat setuju

$S$ : Setuju

$\mathrm{N}$ : Netral

TS : Tidak setuju

Nilai (3)
Nilai (5)

Nilai (4)

Nilai (2)

Nilai (5)

STS : Sangat tidak setuju Nilai (1)

\begin{tabular}{|l|l|l|l|l|l|}
\hline Pernyataan & STS & TS & N & S & SS \\
\hline $\begin{array}{l}\text { Berbagai tuntutan waktu dari pekerjaan saya sebagai } \\
\text { pejabat struktural membuat tidak nyaman untuk } \\
\text { berkumpul dalam keluarga dan melaksanakan berbagai } \\
\text { tanggung jawab pribadi. }\end{array}$ & & & & & \\
\hline $\begin{array}{l}\text { Dengan adanya kewajiban yang berkaitan dengan } \\
\text { pekerjaan sebagai pejabat struktural, saya kadang harus } \\
\text { membuat berbagai perubahan terhadap rencana-rencana } \\
\text { saya tentang waktu pribadi maupun berbagai aktivitas } \\
\text { keluarga. }\end{array}$ & & & & & \\
\hline $\begin{array}{l}\text { Hal-hal yang ingin saya lakukan di rumah tidak } \\
\text { sepenuhnya dapat saya lakukan karena berbagai tuntutan } \\
\text { pekerjaan saya sebagai pejabat struktural. }\end{array}$ & & & & & \\
\hline $\begin{array}{l}\text { Berbagai pekerjaan saya sebagai pejabat struktural } \\
\text { kadang membuat sulit untuk bersantai saat di rumah dan } \\
\text { bersama teman. }\end{array}$ & & & & & \\
\hline $\begin{array}{l}\text { Berbagai tuntutan pekerjaan saya sebagai pejabat } \\
\text { struktural mengganggu kehidupan pribadi saya (Rumah, } \\
\text { keluarga atau waktu senggang saya). }\end{array}$ & & & & & \\
\hline $\begin{array}{l}\text { Pekerjaan saya sebagai pejabat struktural menyulitkan } \\
\text { saya untuk memenuhi berbagai kewajiban pribadi } \\
\text { maupun keluarga. }\end{array}$ & & & & & \\
\hline $\begin{array}{l}\text { Saya mengesampingkan berbagai hal yang sedang saya } \\
\text { kerjakan di lembaga ini karena berbagai tuntutan waktu } \\
\text { saya di rumah. }\end{array}$ & & & & & \\
\hline Keluarga dan teman-teman saya kadang menyita waktu & & & & & \\
\hline
\end{tabular}




\begin{tabular}{|c|c|c|c|c|c|}
\hline \multirow{3}{*}{$\begin{array}{l}\text { Pernyataan } \\
\text { yang saya akan gunakan untuk bekerja. } \\
\text { Saya mengalami masalah dalam berbagai hal di lembaga } \\
\text { ini karena berbagai tuntutan dari keluarga atau } \\
\text { pasangan. }\end{array}$} & STS & TS & $\mathbf{N}$ & $\mathbf{S}$ & SS \\
\hline & & & & & \\
\hline & & & & & \\
\hline $\begin{array}{l}\text { Kesemrawutan yang berkaitan dengan keluarga } \\
\text { mengganggu kemampuan saya untuk melakukan } \\
\text { berbagai kewajiban yang berkaitan dengan pekerjaan saya } \\
\text { sebagai pejabat structural. }\end{array}$ & & & & & \\
\hline $\begin{array}{l}\text { Berbagai tuntutan keluarga atau pasangan saya } \\
\text { mengganggu berbagai aktivitas yang berhubungan } \\
\text { dengan pekerjaan saya sebagai pejabat struktural. }\end{array}$ & & & & & \\
\hline $\begin{array}{l}\text { Kehidupan rumah tangga saya mengganggu berbagai } \\
\text { tanggung jawab saya di lembaga ini seperti } \\
\text { menyelesaikan pekerjaan tepat waktu, menyelesaikan } \\
\text { tugas-tugas harian dan kerja lembur sebagai pejabat } \\
\text { struktural. }\end{array}$ & & & & & \\
\hline $\begin{array}{l}\text { Saya lebih menikmati pekerjaan saya sebagai pejabat } \\
\text { struktural lebih dari waktu senggang saya. }\end{array}$ & & & & & \\
\hline Setiap hari saya yakin pekerjaan saya akan selalu berhasil & & & & & \\
\hline $\begin{array}{l}\text { Saya merasa bahagia dalam pekerjaan saya sekarang } \\
\text { sebagai pejabat struktural. }\end{array}$ & & & & & \\
\hline $\begin{array}{l}\text { Saya puas dengan pekerjaan saya sebagai pejabat } \\
\text { struktural karena tunjangan yang saya peroleh sepadan } \\
\text { dengan pekerjaan saya. }\end{array}$ & & & & & \\
\hline $\begin{array}{l}\text { Pekerjaan saya sebagai pejabat struktural bagaikan suatu } \\
\text { kegemaran bagi saya. }\end{array}$ & & & & & \\
\hline $\begin{array}{l}\text { Saya sungguh-sungguh menyukai pekerjaan sebagai } \\
\text { pejabat struktural. }\end{array}$ & & & & & \\
\hline $\begin{array}{l}\text { Saya menganggap pekerjaan saya sebagai pejabat } \\
\text { strukturalmenyenangkan }\end{array}$ & & & & & \\
\hline $\begin{array}{l}\text { Saya merasa bahwa pekerjaan saya sebagai pejabat } \\
\text { struktural lebih menarik dari pada pekerjaan lain yang } \\
\text { bisa saya dapatkan. }\end{array}$ & & & & & \\
\hline $\begin{array}{l}\text { Saya selalu mendapat dukung dari rekan kerja atas } \\
\text { berbagai pekerjaan saya sebagai pejabat struktural. }\end{array}$ & & & & & \\
\hline $\begin{array}{l}\text { Banyak hal positif yang dapat saya temukan dari rekan } \\
\text { kerja selama bekerja sebagai pejabat struktural. }\end{array}$ & & & & & \\
\hline $\begin{array}{l}\text { Saya bertekad memberikan bantuan yang lebih untuk } \\
\text { lembaga ini agar berhasil. }\end{array}$ & & & & & \\
\hline $\begin{array}{l}\text { Seringkali, saya ikut berpartisipasi berbagai kebijakan } \\
\text { lembaga ini atas berbagai hal penting yang berkaitan } \\
\text { dengan karyawan. }\end{array}$ & & & & & \\
\hline Saya benar-benar peduli terhadap nasib lembaga ini. & & & & & \\
\hline $\begin{array}{l}\text { Saya menemukan bahwa nilai-nilai yang saya yakini dan } \\
\text { nilai-nilai yang diyakini lembaga ini sangat mirip. }\end{array}$ & & & & & \\
\hline $\begin{array}{l}\text { Saya dapat bekerja dengan baik bagi lembaga ini walau } \\
\text { jenis pekerjaan yang saya lakukan berbeda dengan } \\
\text { pekerjaan yang saya lakukan saat ini. }\end{array}$ & & & & & \\
\hline
\end{tabular}




\begin{tabular}{|l|l|l|l|l|l|}
\hline Pernyataan & STS & TS & N & S & SS \\
\hline $\begin{array}{l}\text { Saya sangat senang bahwa saya memilih lembaga ini } \\
\text { untuk bekerja dari pada organisasi yang lain yang telah } \\
\text { saya pertimbangkan pada saat bergabung dengan } \\
\text { lembaga ini. }\end{array}$ & & & & & \\
\hline $\begin{array}{l}\text { Saya merasa nyaman dengan kondisi kerja di lembaga } \\
\text { saat ini. }\end{array}$ & & & & & \\
\hline $\begin{array}{l}\text { Bagi saya, lembaga ini adalah hal yang terbaik dari } \\
\text { semua kemungkinan lembaga tempat saya bekerja. }\end{array}$ & & & & & \\
\hline $\begin{array}{l}\text { Memutuskan untuk bekerja di lembaga ini merupakan } \\
\text { sebuah hal yang positif bagi saya. }\end{array}$ & & & & & \\
\hline
\end{tabular}

